\title{
MORPHOLOGICAL AND PHYLOGENETIC CHARACTERIZATION OF PESTALOTIOPSIS IN RELATION TO HOST ASSOCIATION
}

\author{
KAMHAWY, M.A.M, MAGGIE E. M. HASSAN, SAHAR A. SHARKAWY \\ AND NOHA F. EL-BADAWY
}

Plant Pathol. Res. Inst., ARC, Giza

(Manuscript received 4 August 2010 )

\begin{abstract}
Cross-inoculation studies of fifteen Pestalotiopsis isolates collected from different hosts and locations revealed that the fungus is a non specific pathogen. Isolates were able to attack apple, avocado, date-palm, guava, mango and pomegranate causing leaf spot and fruit rot. Disease severity and disease symptoms varied according to plant species. Guava plants was the most susceptible host, all being attacked by tested isolates resulting in brown leaf spot followed by pomegranate, while date palm was least affected. Avocado isolate (P6) was more aggressive on all tested plants, while date palm isolate (P12) was weakest. Six primers were used to determine the degrees of similarity among the tested isolates through RAPD - PCR. Isolates from the same host were not phylogenetically close - related. A close phylogenetic relationship among isolates possessing similar morphological characters was observed.

Key words: Pestalotiopsis, host association, cross inoculation, morphological characters, DNA fingerprinting.
\end{abstract}

\section{INTRODUCTION}

Species of Pestalotia are common pathogens an a broad variety of plants found in the temperate and tropical regions of the world (Fail and Langenheim, 1990). Some species appear to grow primarily as saprophytes, whereas others are more aggressive and cause severe leaf blights, especially on trees (Arrhenius and Langenheim,1986). Although there are few detailed investigations on the infection process of these fungi, it is apparent that they often exhibit latent infections and are more aggressive as pathogens in tissue that has been wounded (Fail and Langenheim, 1990). Uchida (2004) reported that Pestalotia is a wide spread plant pathogen in different parts of the world as well as in Egypt. It attacks a large number of fruit trees causing several diseases.Pestalotia infection does not kill the plant entirely but the biosynthetic capacity of the tree is undoubtedly reduced. Besides the above mentioned, Pestalotia has been observed on a number of hosts of great economic importance. No detailed account of the total amount of loss incurred has been estimated. Joshi (2005) reported that Pestalotia fungus attacks cashews and the symptoms can be observed as minute irregular necrotic patches of brick red colour at 
the leaf margins which enlarged, turned grey-silver in colour and covered the major portion of the leaf lamina.

The use of various nucleic acid-based techniques for the detection and identification of microorganisms has dramatically increased in recent years and may provide highly specific tools for such purposes. Restriction fragment length polymorphisms (RFLPs), which are costly and time consuming, can be used; however, the random amplified polymorphic DNA (RAPD) is also a useful technique to evaluate taxonomic identity. The application of (RAPD) to produce isolate-specific DNAfingerprints is especially promising (Welsh and McClelland, 1990 and Williams et al., 1990). This technique has the advantage of that no DNA base sequence information of the organism is needed. The technical simplicity and speed of RAPD methodology is a principal advantage over other techniques (Gepts, 1993).

The aim of this work was to determine pathogenic capabilities, cross infectivity of Pestalotiopsis isolates and to uncover the genetic diversity among some isolates through the use of RAPD method.

\section{MATERIALS AND METHODS}

\section{1-Sources of Pestalotiopsis isolates}

Fifteen isolates of Pestalotiopsis fungus, obtained from six different hosts showing different symptoms and from various governorates of Egypt, were used in this study. These isolates were obtained from Research Department of Fruit and Woody Trees Disease, Plant Pathology Institute, A.R.C. Details of the obtained isolates are tabulated in Table(1).

\section{Pathogenicity and Cross-inoculation studies of Pestalotiopsis isolates}

Pathogenic capabilities on alternative hosts of Pestalotiopsis iosolates were determined using excised, 20-30 cm long of twigs, apparently free from mechanical injury or diseases, were carefully chosen of the following plants, "Guava" (Psidium guajava L.), "Pomegranate"(Punica granatum L.), "Avocado"(Persea americana L.), "Mango"(Mangifera indica L.), and "Apple"(Malus domestica Borth). Seedlings, one years old originated from seeds, were used for "Date palm"(Phoenix dactylifera L.). Excised twigs were thoroughly washed with tap water, surface sterilized by $70 \%$ ethanol using atomizer and air dried. The base of excised twigs were put in conical flasks containing nutrient Hewitt's solution (Hewitt, 1952) covered with aluminum foil to prevent light.

\section{Preparation of pathogen inocula}

Inocula were prepared as previously described by Ker Chung and Hoch (1996). Spore suspension was strained through two layers of cheesecloth to remove mycelial clumps. 
Conidiospore concentration was determined and adjusted with a haemocytometer to $10^{6}$ spore / $\mathrm{ml}$ approximately then, excised twigs of different host plants and date palm seedling were rubbed gently with a hair brush and then sprayed using an atomizer to the point of run off. Inoculated plants were covered with large plastic bags to maintain high humidity for two days. Control plants were similarly treated with sterile distilled water. Five replicates plants were used for each treatment.

Table 1. Isolates of Pestalotia used in this study, their hosts, symptoms and sample origin.

\begin{tabular}{|c|c|c|c|}
\hline Code No. of isolates & Hosts & Symptoms & governorate \\
\hline $\begin{array}{c}\text { Pestalotiopsis psidii } \\
\text { (P1) }\end{array}$ & $\begin{array}{c}\text { "Guava" } \\
\text { (Psidium guajava L.) }\end{array}$ & Guava Leaf Spot & Menofia \\
\hline $\begin{array}{c}\text { Pestalotiopsis psidii } \\
\text { (P2) }\end{array}$ & $\begin{array}{c}\text { "Guava" } \\
\text { (Psidium guajava L.) }\end{array}$ & Guava Canker & Beheira \\
\hline $\begin{array}{c}\text { Pestalotiopsis psidii } \\
\text { ( P3) }\end{array}$ & $\begin{array}{c}\text { "Guava" } \\
\text { (Psidium guajava L.) }\end{array}$ & Root Rot & Beheira \\
\hline $\begin{array}{c}\text { Pestalotiopsis sp. } \\
\text { ( P4) }\end{array}$ & $\begin{array}{c}\text { "Pomegranate" } \\
\text { (_Punica granatum L.) }\end{array}$ & Leaf and Flower Spot & Asyut \\
\hline $\begin{array}{l}\text { Pestalotiopsis sp. } \\
\text { (P5) }\end{array}$ & $\begin{array}{c}\text { "Pomegranate" } \\
\text { (Punica granatum L.) }\end{array}$ & Leaf and Flower Spot & Asyut \\
\hline $\begin{array}{l}\text { Pestalotiopsis } \\
\text { palmarum } \\
\text { (P6) }\end{array}$ & $\begin{array}{c}\text { "Avocado" } \\
\text { (Persea americana L.) }\end{array}$ & Leaf Spot and Fruit canker & Qalyubia \\
\hline $\begin{array}{c}\text { Pestalotiopsis } \\
\text { palmarum } \\
\text { (P7) }\end{array}$ & $\begin{array}{c}\text { "Avocado" } \\
\text { (Persea Americana L.) }\end{array}$ & Leaf Spot and Fruit canker & Qalyubia \\
\hline $\begin{array}{c}\text { Pestalotiopsis } \\
\text { mangiferae (P8) }\end{array}$ & $\begin{array}{c}\text { "Mango" } \\
\text { (Mangifera indica L.) }\end{array}$ & Root Rot & Sharqia \\
\hline $\begin{array}{c}\text { Pestalotiopsis } \\
\text { mangiferae. (P9) }\end{array}$ & $\begin{array}{c}\text { "Mango" } \\
\text { (Mangifera indica L.) }\end{array}$ & Root Rot & Beheira \\
\hline $\begin{array}{c}\text { Pestalotiopsis } \\
\text { mangiferae. (P10) }\end{array}$ & $\begin{array}{c}\text { "Mango" } \\
\text { (Mangifera indica L.) }\end{array}$ & Leaf Spot & Gharbia \\
\hline $\begin{array}{c}\text { Pestalotiopsis } \\
\text { mangiferae. (P11) }\end{array}$ & $\begin{array}{c}\text { "Mango" } \\
\text { (Mangifera indica L.) }\end{array}$ & Leaf Spot & Beheira \\
\hline $\begin{array}{c}\text { Pestalotiopsis } \\
\text { palmicola. (P12) }\end{array}$ & $\begin{array}{c}\text { "Date palm" } \\
\text { (Phoenix dactylifera L.) }\end{array}$ & Leaf Spot and Blight & Giza \\
\hline $\begin{array}{c}\text { Pestalotiopsis } \\
\text { palmicola. (P13) }\end{array}$ & $\begin{array}{c}\text { "Date palm" } \\
\text { (Phoenix dactylifera L.) }\end{array}$ & Leaf Spot and Blight & Giza \\
\hline $\begin{array}{c}\text { Pestalotiopsis sp. } \\
\text { ( P14) }\end{array}$ & $\begin{array}{c}\text { "Apple" } \\
\text { (Malus domestica } \\
\text { Borth) }\end{array}$ & Root Rot & Menofia \\
\hline $\begin{array}{c}\text { Pestalotiopsis sp. } \\
\text { ( P15) }\end{array}$ & $\begin{array}{c}\text { "Apple" } \\
\text { (Malus domestica } \\
\text { Borth) }\end{array}$ & Root Rot & Menofia \\
\hline
\end{tabular}

\section{Disease assessment}

Disease assessment was determined for each leaf according to the disease severity rating which include the size and frequency of the lesion / leaf. The following numerical rates were suggested for disease severity:

$0=$ No symptoms. 
$1=$ Few scattered lesions covering about $1-25 \%$ of the leaf.

$2=$ Spots covering about $26-50 \%$ of the leaf.

$3=$ Spots coalescing and covering about $51-75 \%$ of the leaf.

$4=$ Severe infection with coalescing and covering more than $75 \%$ of the leaf.

Disease severity was calculated according to the equation suggested by Townsend and Heuberger (1943) as follows: Disease severity (\%) = sum ( $\mathrm{n} \times \mathrm{r}) \times 100$ / $4 N$. Whereas: $(n)$ is the number of leaves in each numerical grade $(r)$ and $(N)$ is the total number of inoculated leaves multiplied by the maximum numerical grade.

\section{Fruits inoculation}

The same procedure was used to assess the capability of fungal isolates to attack detached fruits of tested plants. With exception of date palm fruits (not available at the time of study). Inoculation was performed by wounding the fruits with 600 mesh carborandum powder. Then, spore suspension of $10^{5} \mathrm{spore} / \mathrm{ml}$ approximately was atomized onto fruits of tested hosts. Control fruit were similarly treated with sterile distilled water. Five replicates were used for each treatment. After inoculation, fruits packed into transparent plastic bag to serve as a moist chamber for $48 \mathrm{~h}$ at room temperature $\left(28 \pm 2^{\circ} \mathrm{C}\right)$ to ensure high humidity during the infection process. After 48 hour, the inoculated fruits were unpacked and left at room temperature with a daily check for symptoms development.

\section{Variation among Pestalotiopsis isolates}

The 15 single spore isolates were grown on PDA medium. Cultures were incubated at $24^{\circ} \mathrm{C}$ under continuous light, and cultural morphology was examined after 7 days. Colony color was defined according to Raynor (1970). Spore dimension was determined for 30 randomly selected conidia of each isolate in sterile distilled water. The isolates were characterized, initially, by comparing morphological and cultural characteristics (i.e., size of conidia, length of apical and basal appendages).

\section{Molecular characterization}

\section{Extraction of genomic DNA}

DNA was extracted from $50 \mathrm{mg}$ of mycellium using Qiagen Kit for DNA extraction. The extracted DNA was dissolved in $100 \mathrm{ul}$ of elution buffer. The concentration and purity of the obtained DNA was determined by using "Gen qunta" system-Pharmacia Bio-tech. The purity of the DNA for all samples was $90-97 \%$ based on the 1.6 and 1.8 ratio.The DNA concentration was adjusted at $6 \mathrm{ng} / \mathrm{ul}$ for all samples in TE buffer $\mathrm{pH}$. 8.0.

\section{Random amplified polymorphism DNA (RAPD) technique}

RAPD amplification was generally carried out using six different random primers shown in Table (2). Each 25 ul reaction mixture contained 1 unit of Taq DNA polymerase, 0.2 
$\mathrm{mM}$ each dNTP, $1 x$ PCR buffer, $3 \mathrm{mM} \mathrm{MgCl} 2,10 \mathrm{pmol}$ of primer and approximately 50 ng of template genomic DNA. PCR condition was as follows: initial denaturation at 95 ${ }^{\circ} \mathrm{C}$ for $5 \mathrm{~min}$, followed by 45 cycles of denaturation at $95{ }^{\circ} \mathrm{C}$ for $1 \mathrm{~min}$, annealing at 36 ${ }^{\circ} \mathrm{C}$ for I min and extension at $72^{\circ} \mathrm{C}$ for 2 min followed by a final extension cycle at $72^{\circ} \mathrm{C}$ for 10 min then held at $4^{\circ} \mathrm{C}$. The amplified products were separated on $2 \%$ agarose gel at 75 constant volt, using $1 \mathrm{X}$ TBE buffer followed by staining with ethidium bromide solution ( $1 \mathrm{ug} / \mathrm{ml}$ ), and the bands were visualized with UV transilluminator. All gels were scanned for band $R_{f}$ using gel documentation system (AAB). The M.W. of bands were determined against DNA marker Ameresco (100 bp) K 800 and phenograms were based on unweighted pair-group method of arithmetic means (UPGMA).

Table 2. list of primers used in this study along with their sequences.

\begin{tabular}{|c|c|}
\hline Primer code & Sequence $\left(\mathbf{5}^{\prime}-\mathbf{-} \mathbf{3}^{\prime}\right)$ \\
\hline Primer 1 & GGTGCGGGAA \\
\hline Primer 2 & GTTTCGCTCC__ \\
\hline Primer 3 & GTAGACCCGT \\
\hline Primer 4 & AAGAGCCCGT \\
\hline Primer 5 & AACGCGCAAC \\
\hline Primer 6 & CCCGTCAGCA \\
\hline
\end{tabular}

\section{RESULTS AND DISCUSSION}

\section{Pathogenicity and Cross infectivity of Pestalotiopsis isolates}

The aim of this study is to determine the pathogenicity of Pestalotiopsis isolates from the six different hosts as well as to uncover possible cross pathogenicity. Results (Table 3and Fig. 1) showed that the pathogen was able to attack apple, avocado, date-palm, guava, mango and pomegranate, however, disease severity and disease symptoms varied according to the plant species. Guava plants were the most susceptible host as all the tested isolate were able to infect causing leaf spots, however, with different degrees. Isolates were not necessarily more virulent to the hosts from which they were isolated. For example, isolates 4 and 5 from pomegranate and isolates 5 and 7 from avocado and isolates 8 and 9 from mango were highly pathogenic to guava. Isolates P1 - P7 were also more pathogenic than other isolates. It was also obvious that larger number of compatible reactions (high disease severity) in case of guava and pomegranate with Pestalotiopsis isolates compared with other host/pathogen combinations. Such a non-host specific property of the pathogen 
provides a variety of sources for inoculum in nature. Such results are in agreement with those of Jeewon, et al. (2004) who reported that, although many species names of Pestalotiopsis (Pestalotia) refer to the host species from which they were recovered, some investigations have shown that Pestalotiopsis species are not highly hostspecific. Pestalotiopsis species ( Deuteromycetes, Melanoconiales ) are common in both temperate and tropical ecosystems and frequently are associated with leaves of woody plants. Most Pestalotia species in the tropics have caused.

Table 3. Pathogenic capabilities and Cross - inoculation studies of Pestalotiopsis isolates.

\begin{tabular}{|c|c|c|c|c|c|c|c|}
\hline \multirow{2}{*}{$\begin{array}{l}\text { Code } \\
\text { No. of } \\
\text { isolates }\end{array}$} & \multicolumn{7}{|c|}{ \%disease severity 15 days after inoculation } \\
\hline & Avocado & Apple & Date Palm & Guava & Mango & Pomegranate & Mean \\
\hline P1 & 2.10 & 3.7 & 0.0 & 8.3 & 0.0 & 16.1 & 5.33 \\
\hline $\mathbf{P 2}$ & 3.92 & 4.2 & 0.0 & 17.0 & 0.0 & 17.4 & 7.09 \\
\hline P3 & 6.87 & 5.2 & 0.0 & 4.2 & 0.0 & 13.0 & 4.87 \\
\hline P4 & 2.5 & 2.0 & 3.3 & 143 & 2.7 & 20.0 & 6.07 \\
\hline P5 & 5.93 & 2.7 & 0.0 & 20.8 & 3.3 & 20.0 & 8.78 \\
\hline P6 & 5.0 & 1.7 & 4.0 & 26.4 & 5.0 & 15.0 & 9.51 \\
\hline P7 & 4.2 & 0.0 & 5.7 & 16.43 & 5.7 & 19.0 & 8.50 \\
\hline P8 & 3.7 & 3.0 & 0.0 & 21.0 & 4.0 & 3.0 & 5.78 \\
\hline P9 & 2.5 & 3.0 & 6.6 & 23.2 & 5.7 & 6.87 & 7.97 \\
\hline P10 & 6.6 & 3.0 & $0 . .9$ & 2.4 & 1.1 & 10.0 & 5.65 \\
\hline P11 & 5.2 & 4.6 & 1.36 & 4.5 & 2.9 & 3.3 & 3.64 \\
\hline P12 & 0.0 & 3.3 & 7.18 & 3.0 & 1.8 & 0.0 & 4.69 \\
\hline P13 & 0.0 & 33 & 1.69 & 2.5 & 1.8 & 0.0 & 1.99 \\
\hline P14 & 2.10 & 6.9 & 0.0 & 2.9 & 0.0 & 2.9 & 2.46 \\
\hline P15 & 1.80 & 10.0 & 0.0 & 7.18 & 0.0 & 3.92 & 3.82 \\
\hline Mean & 3.49 & 3.21 & 2.16 & 11.61 & 2.66 & 9.41 & \\
\hline \multicolumn{8}{|c|}{ L.S.D at 0.05 for: Isolates(I) $=0.39$} \\
\hline & & \multicolumn{2}{|c|}{ Hosts $(H)=0.25$} & \multicolumn{4}{|c|}{ P6,P7:avocado,P8,P9,P10,P11:mano, } \\
\hline & & \multicolumn{2}{|c|}{$\mathrm{I} X \mathrm{XH}=0.9$} & \multicolumn{4}{|c|}{ P12,P13:date palm ,P14,P15:apple } \\
\hline
\end{tabular}

serious leaf blighting on trees, the fungus Pestalotiopsis (Pestalotia) is not host specific, and has been isolated from a wide variety of palms (Fail and Langenheim 1990). Wounds or plant damage of different causes often seems to be a prerequisite for infection and disease development (Elliott, 2006). The disease symptoms on the artificially infected apple leaves can be seen as faint brown spot surrounded by yellow halo. It is also clear from the same Fig $(1, \mathrm{~B})$ that the symptoms on apple fruit are faint brown like cavity turned to dark brown with age. Pestalotia malicola is known to attack several members of the Rosaceae, including apple and pear as well as other fruits (Ozoe et al., 1967). It is also clear that Pestalotiopsis isolates can attack avocado leaves and fruits, the symptoms on leaves are seen as circular dark brown spots on both leaves and fruits that can coalesce with each other to cover more area of the fruit (Fig.1C and D). 


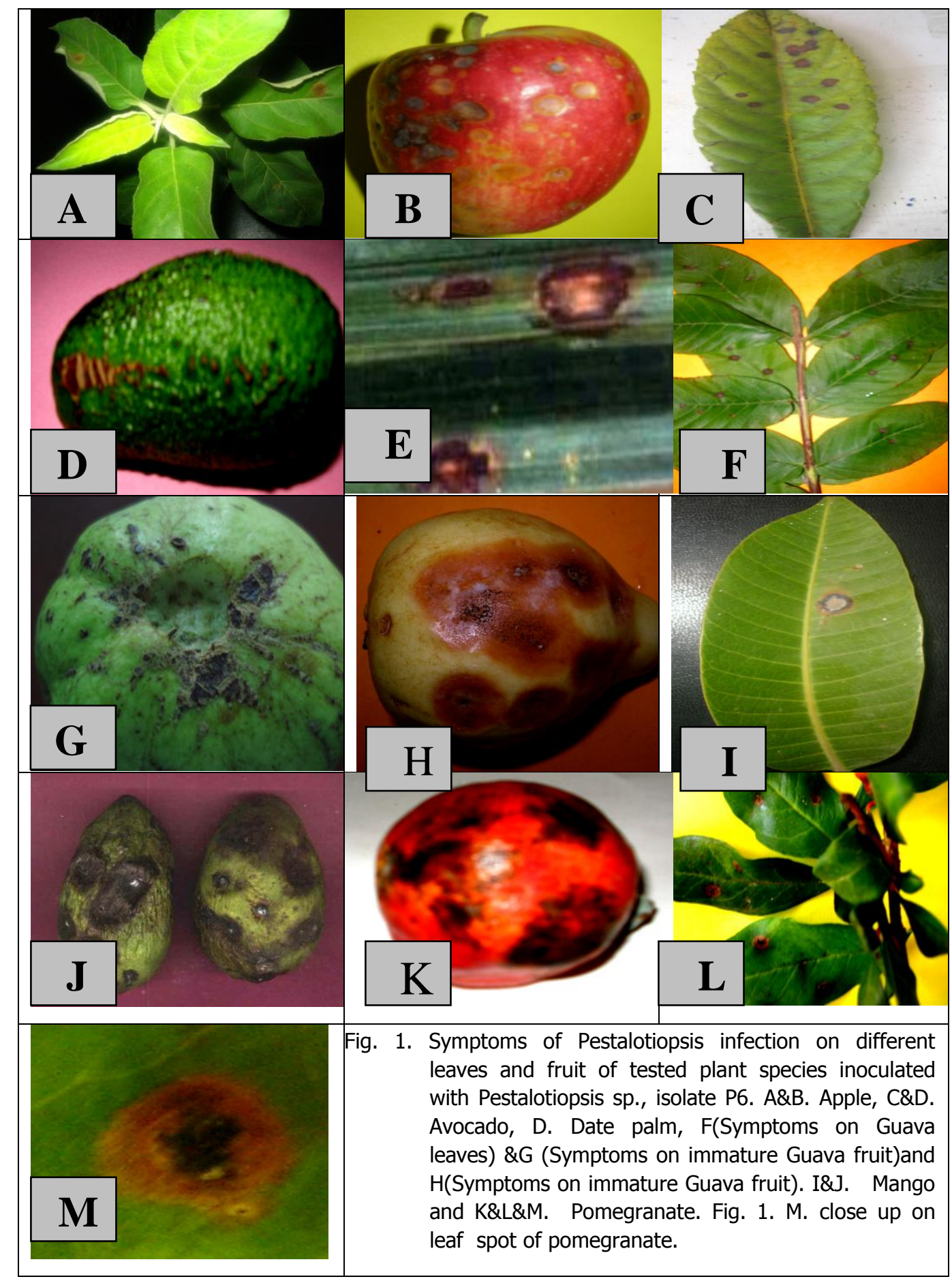

The symptoms on date- palm are brown leaf spots being surrounded by a chlorotic halo with age with the center of the spots turning grey and fell out (Fig. 1.E). Disease symptoms on mango consisted of tiny circular, light grey colored spots and brown rot spot on fruit with acervuli on them and a rusty halo. Spots became larger, tended to coalesce and darken (Fig.1I\&J), finally resulting fruit rot. These results are in 
agreement with those reported by Ko, et al. (2007). Pomegranate infection

(Fig. 1 $\mathrm{K} \& \mathrm{~L})$ can be seen as circular to somewhat angular dark reddish brown to almost black surrounded by a diffuse orange halo.

\section{Culture Morphology}

Morphological characteristics of typical cultures Pestalotiopsis isolates are shown in Figure (2) on PDA. Most of the isolates first developed grayish to white zonate colonies that later developed color and small, acervular conidiomata. Acervuli were black for all isolates examined. The color became darker as culture age increased. The 15 isolates of Pestalotiopsis could be separated into three main groups based on their color on PDA (Fig. 2). However, color groups did not separate into species (Lisa et al., 2006). The first group, buff (top) and pale luteous (bottom), included guava isolates, P2 , P5 pomegranate isolate, P6\&7, P9 (mango) and P15 (apple). The second group, pale buff (top) and (bottom side), included isolates 1, 3, 8, 11, 12,13and 14, while the remaining isolates fell into the third category, with white mycelium. However, acervula production varied from abundant concerning the entire PDA plate (isolates 2, $3,4,6,8,11$ and 13) to moderate in the center of the PDA plate (isolates 1, 7 and 15) and the remaining isolates reducing sparse very Acervuli formed after 10days. The conidia were multi-cellular with usually three darkly pigmented center cells and clear pointed end cells. Conidia shape was ellipsoid or fusoid. A diagnostic feature is the two or more clear, whisker-like appendages arising from the end cell. On the basis of conidial morphology (Fig. 2 P16-P18), our isolates possessed five-celled conidia, of which apical and basal cells were hyaline, and the three median cells from light brown to dark brown or olive green (Fail and Langenheim, 1990). Measurements of conidia revealed few differences in size among isolates from the same host as well from different hosts. Spore measurements varied from 21.43 to $28.92 \mu \mathrm{m}$ mean length and 4.64 to $8.71 \mu \mathrm{m}$ mean width. 


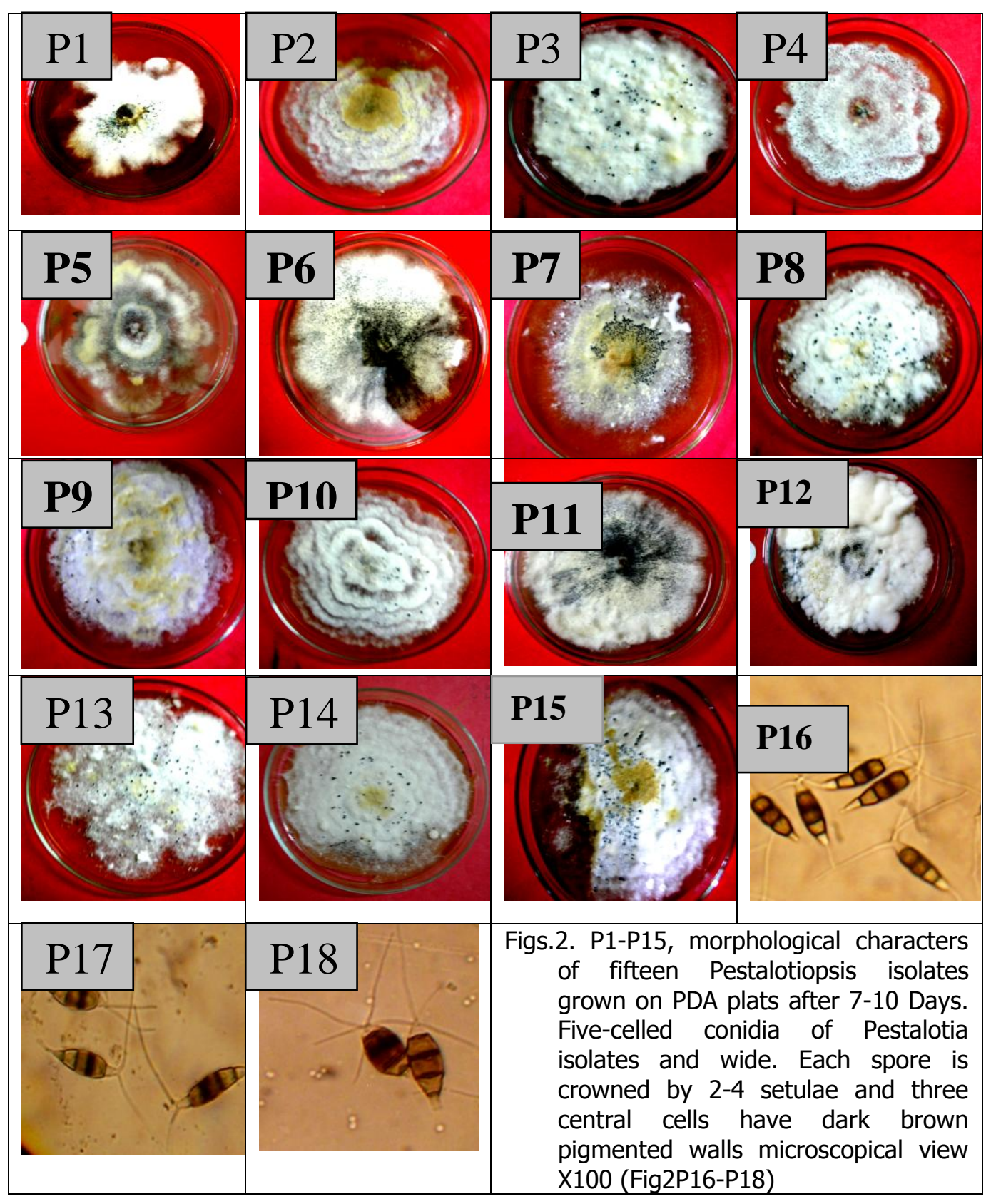

Basal appendages were hyaline, straight or slightly curved, and varied from 4.0 to $5.3 \mu \mathrm{m}$ mean length. Number of apical appendages ranged from two to four, with three being the most common. 
Table 4. Characteristics of conidia of Pestalotiopsis isolates.

\begin{tabular}{|c|c|c|c|c|}
\hline $\begin{array}{l}\text { Code No. of } \\
\text { isolates }\end{array}$ & $\begin{array}{l}\text { Size of Conidia } \\
(\mu \mathrm{m}) \\
\underline{\mathrm{L}} \quad \underline{\mathrm{W}}\end{array}$ & $\begin{array}{l}\text { No. of } \\
\text { Apical } \\
\text { appendage }\end{array}$ & $\begin{array}{l}\text { length. of Apical } \\
\text { appendage ( } \mu \mathrm{m})\end{array}$ & $\begin{array}{c}\text { Basal } \\
\text { appendage } \\
\text { length }(\mu \mathrm{m})\end{array}$ \\
\hline P1 & $\begin{array}{c}26-32 \times 6-8 \\
\text { Average } \\
(28.92 \pm 0.2 \times 7.27 \pm 0.07 \\
\end{array}$ & $2-3$ & $19.0 \pm 0.5$ & $4.3 \pm 0.3$ \\
\hline $\mathbf{P 2}$ & $\begin{array}{c}20-32 \times 5.8-8 \\
\text { Average } \\
27.36 \pm 0.4 \times 6.69 \pm 0.07 \\
\end{array}$ & $2-3$ & $17.8 \pm 0.7$ & $4.0 \pm 0.3$ \\
\hline P3 & $\begin{array}{c}20-24 \times 7.2-8 \\
\text { Average } \\
21.86 \pm 0.13 \times 7.74 \pm 0.03\end{array}$ & $2-3$ & $18.3 \pm 0.7$ & $4.5 \pm 0.2$ \\
\hline P4 & $\begin{array}{c}24-32 \times 8-12 \\
\text { Average } \\
25.5 \pm 0.26 \times 9.14 \pm 0.13\end{array}$ & $2-3$ & $13.3 \pm 0.4$ & $2.9 \pm 0.2$ \\
\hline P5 & $\begin{array}{c}20-28 \times 8-12 \\
\text { Average } \\
25.78 \pm 0 . .26 \times 8.71 \pm 0.13 \\
\end{array}$ & $2-4$ & $16.3 \pm 0.4$ & $2.9 \pm 0.2$ \\
\hline P6 & $\begin{array}{c}20-32 \times 8-10 \\
\text { Average } \\
26 \pm 0 . .4 \times 8.14 \pm 0.07 \\
\end{array}$ & $2-4$ & $15.3 \pm 0.4$ & $4.8 \pm 0.3$ \\
\hline P7 & $\begin{array}{c}20-32 \times 8-10 \\
\text { Average } \\
26 \pm 0 . .4 \times 8.35 \pm 0.07\end{array}$ & $2-4$ & $19.3 \pm 0.4$ & $5.0 \pm 0.3$ \\
\hline P8 & $\begin{array}{c}24-28 \times 4-6 \\
\text { Average } \\
24.85 \pm 0.13 \times 4.96 \pm 0.07\end{array}$ & $2-4$ & $20.3 \pm 0.4$ & $4.0 \pm 0.3$ \\
\hline P9 & $\begin{array}{c}24-28 \times 4-6 \\
\text { Average } \\
24.92 \pm 0.13 \times 5.07 \pm 0.07\end{array}$ & $2-3$ & $26.5 \pm 1.3$ & $4.0 \pm 0.3$ \\
\hline P10 & $\begin{array}{c}24-28 \times 5-6 \\
\text { Average } \\
25.35 \pm 0.13 \times 5.35 \pm 0.03 \\
\end{array}$ & $2-4$ & $22.5 \pm 1.0$ & $5.0 \pm 0.3$ \\
\hline P11 & $\begin{array}{c}24-32 \times 5-7 \\
\text { Average } \\
25.78 \pm 0.26 \times 5.74 \pm 0.07 \\
\end{array}$ & $2-4$ & $21.3 \pm 0.6$ & $4.8 \pm 0.3$ \\
\hline P12 & $\begin{array}{c}20-26 \times 8 \\
\text { Average } \\
22.35 \pm 0.13 \times 8 \\
\end{array}$ & $2-4$ & $19.1 \pm 0.6$ & $2.9 \pm 0.2$ \\
\hline P13 & $\begin{array}{c}20-26 \times 8 \\
\text { Average } \\
22.86 \pm 0.2 \times 8 \\
\end{array}$ & $2-3$ & $15.8 \pm 0.5$ & $5.3 \pm 0.3$ \\
\hline P14 & $\begin{array}{c}20-24 \times 4-6 \\
\text { Average } \\
21.43 \pm 0.13 \times 4.64 \pm 0.07\end{array}$ & $2-3$ & $11.6 \pm 0.5$ & $5.3 \pm 0.1$ \\
\hline P15 & $\begin{array}{c}20-24 \times 4-6 \\
\text { Average } \\
21.71 \pm 0.13 \times 4.7 \pm 0.07\end{array}$ & $2-3$ & $11.6 \pm 0.5$ & $5.3 \pm 0.1$ \\
\hline
\end{tabular}

Each value is the mean \pm SE in measurements of conidia.

The appendages showed the most size variation, with mean lengths ranging from 11.6 to $26.5 \mu \mathrm{m}$ (Table 4 ). 


\section{Genetic variations among the tested Pestalotiopsis isolates}

Six different 10 mer primers were used to study the genetic variation among the fifteen isolates of Pestalotiopsis collected from different hosts and locations in Egypt. The RAPD profile of amplification products generated with primers is presented in Fig.4 (a-f). All the used primers revealed a high degree of similarities among the tested isolates.

The cluster of the isolates with primer 1 revealed that Pestalotia isolates can be grouped into a number of sub clusters. Isolate no. 1 can be grouped with isolates no. 2 \& 3 with $96.91 \%$ similarity, and these isolates from the same host and have the same number of apical appendage. In addition by using primers $3 \& 6$ isolate 4 and 5 were grouped together with $98 \%$ similarity, both isolates were isolated from pomegranate and have the same basal appendage length. By using primers 1,2,3,4 and 6, isolates 6 and 7 located in the same group with similarity ranged from 96.9 to 99.8 , all of them isolated from avocado, they were more aggressive to all tested plants, they were located in the first group based on their color on PDA and they have the same number of apical appendage. Primers 3, 4, 5 and 6 divided isolates 8,9,10 \& 11, which isolated from mango plants, into two groups. Isolate 8 was grouped with isolate 9 with $99 \%$ similarity, and they have the same basal appendage length. Meanwhile, isolate 10 was grouped with isolate 11 with similarity ranged from 90.9 with primer 4 to 98.8 with primer 3. All six primers presented isolates $12 \& 13$ from date-palm in the same group with similarity 99\%. Primers $5 \& 6$ located isolates 5 and 6 in one group with similarity ranged from 93.76 to 99.08 , both of them isolated from apple plant, they have the same number of apical appendage and the same basal appendage length. The advent of DNA based molecular methods helped to study inter - and intraspecific variation in filamentous 
$\begin{array}{llllllllllllllll}M & 1 & 2 & 3 & 4 & 5 & 6 & 7 & 8 & 9 & 10 & 11 & 12 & 13 & 14 & 15\end{array}$

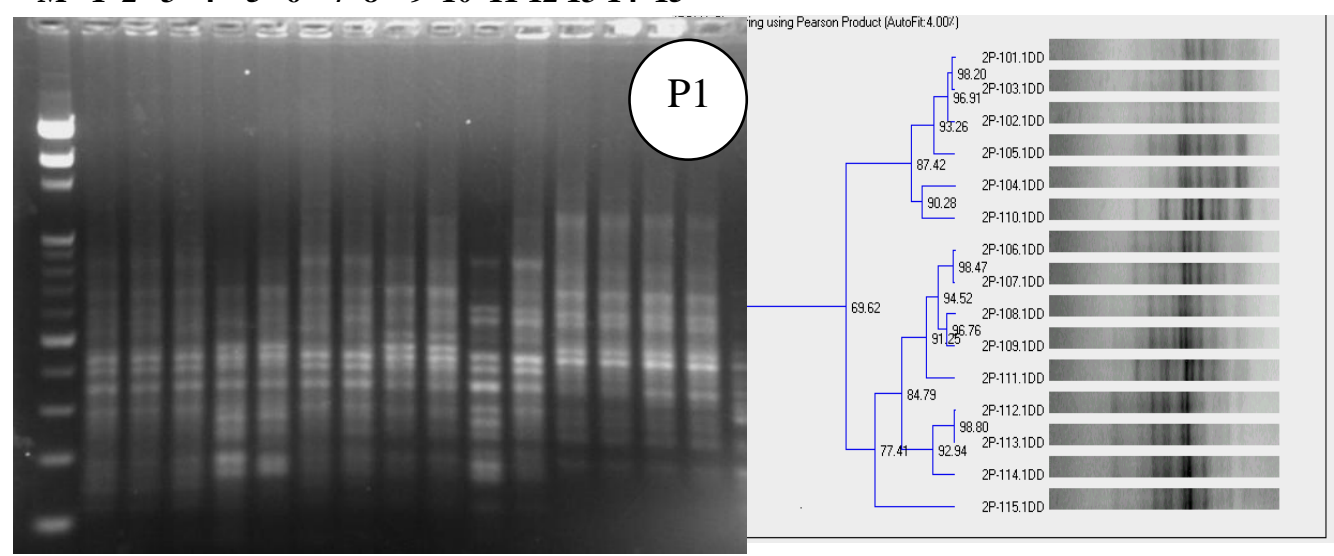

$\begin{array}{llllllllllllllll}M & 1 & 2 & 3 & 4 & 5 & 6 & 7 & 8 & 9 & 10 & 11 & 12 & 13 & 14 & 15\end{array}$

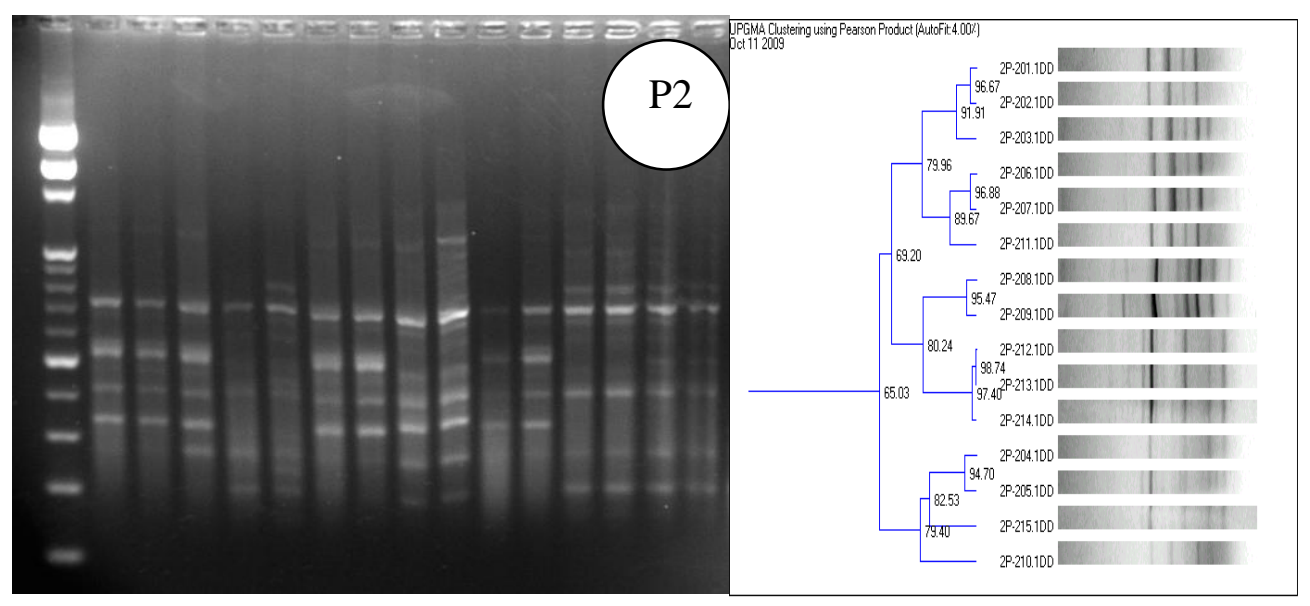

$\begin{array}{llllllllllllllll}M & 1 & 2 & 3 & 4 & 5 & 6 & 7 & 8 & 9 & 10 & 11 & 12 & 13 & 14 & 15\end{array}$

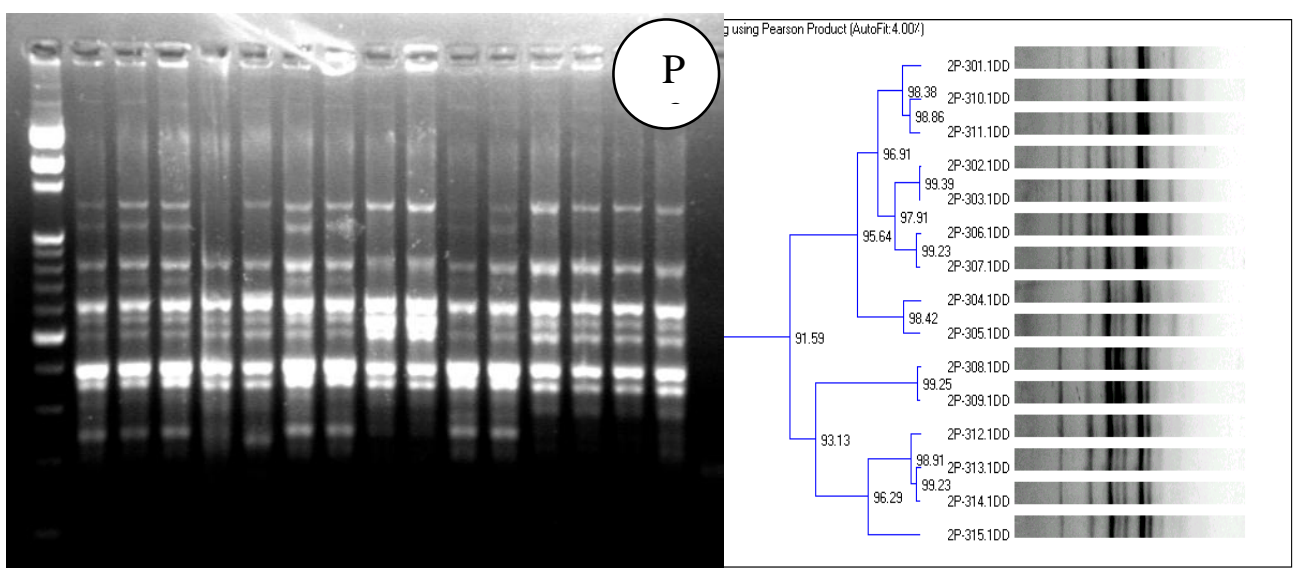

Fig. 4. DNA amplified banding patterns based on RAPD and UPGMA cluster analysis for Pestalotiopsis Isolates ( $1-15)$ using different primers (P1-P3). M: DNA marker (1000-50 bp ). 
$\begin{array}{lllllllllllllll}M & 1 & 2 & 3 & 4 & 5 & 6 & 7 & 8 & 9 & 10 & 11 & 12 & 13 & 14\end{array}$

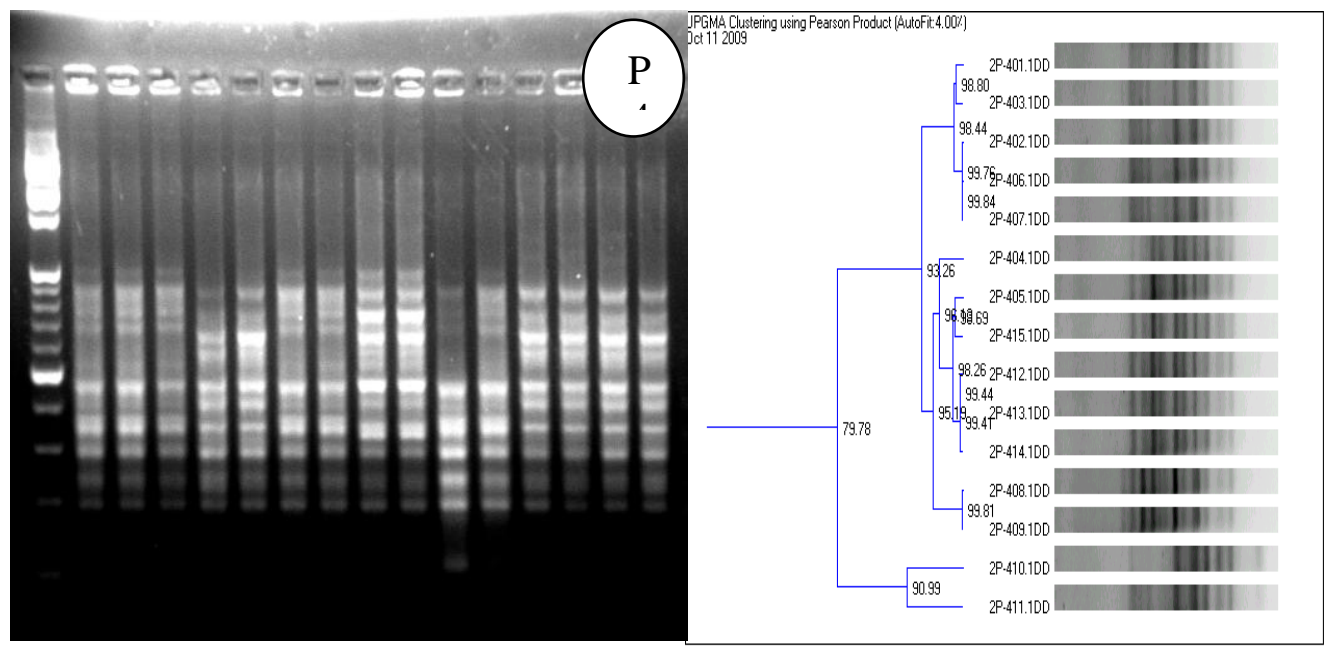

$\begin{array}{llllllllllllllll}M & 1 & 2 & 3 & 4 & 5 & 6 & 7 & 8 & 9 & 10 & 11 & 12 & 13 & 14 & 15\end{array}$

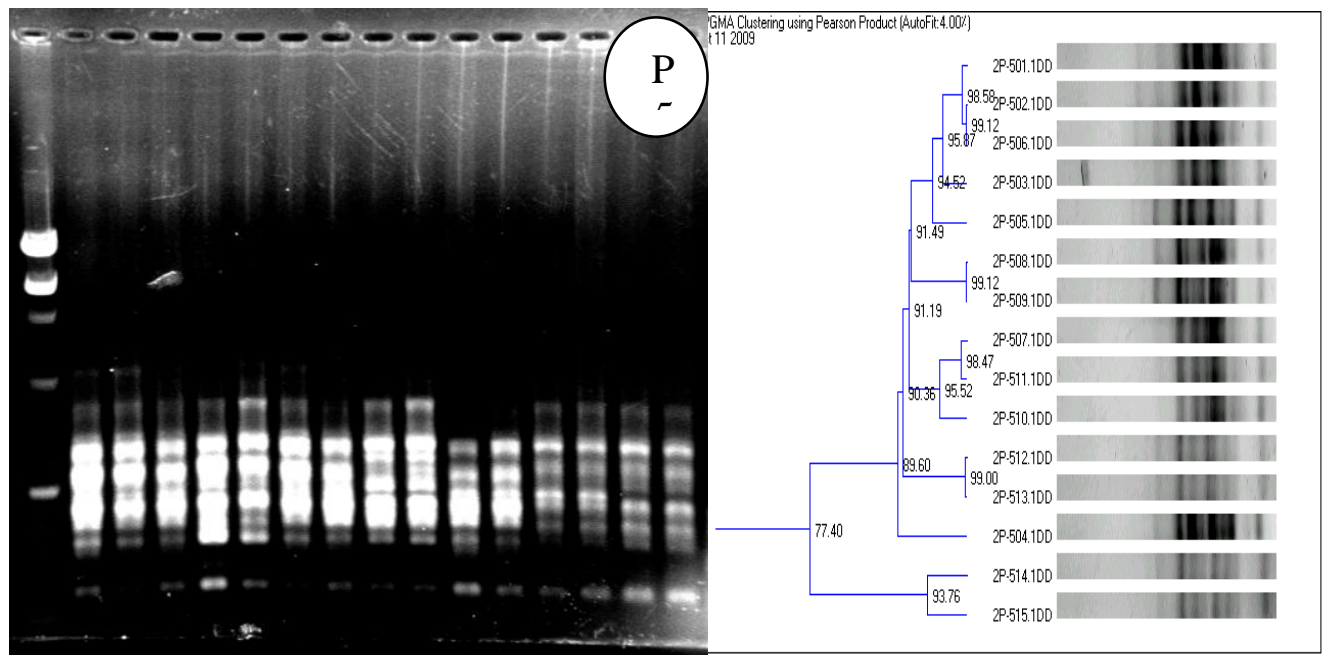

$\begin{array}{llllllllllllllll}M & 1 & 2 & 3 & 4 & 5 & 6 & 7 & 8 & 9 & 10 & 11 & 12 & 13 & 14 & 15\end{array}$

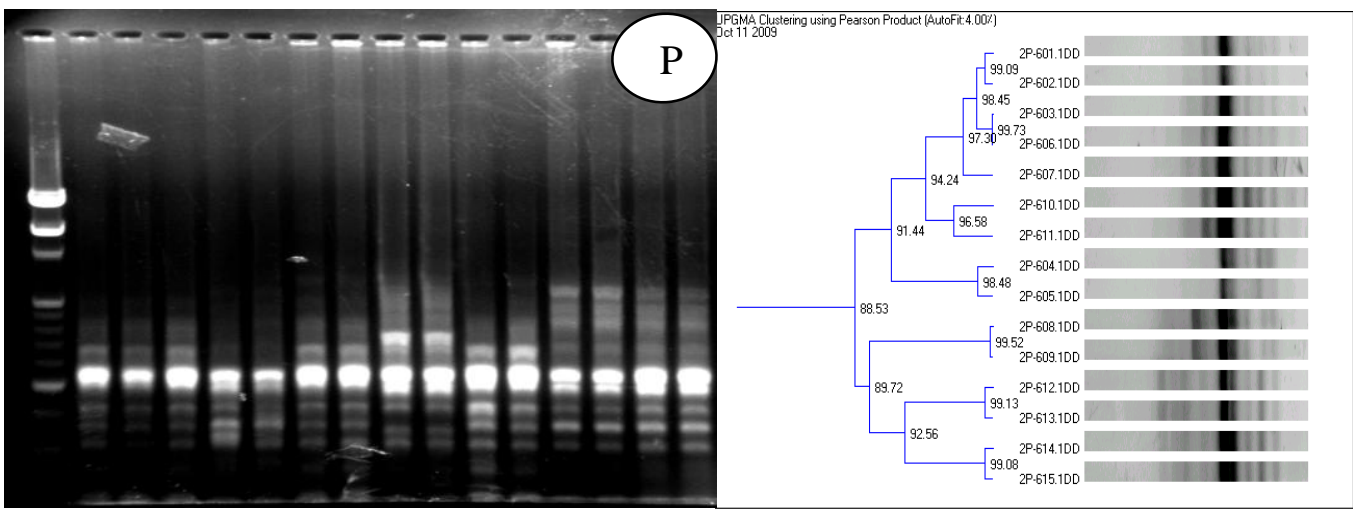

Fig. 4. DNA amplified banding patterns based on RAPD and UPGMA cluster analysis for Pestalotiopsis Isolates ( 1-15) using different primers (P4-P6). M: DNA marker (1000$50 \mathrm{bp})$. 
fungi. In the present study, we have used RAPD-PCR method to study the genetic diversity among Pestalotia isolates. DNA pattern from morphologically similar and dissimilar taxa from the same and different hosts were analyzed in order to establish whether species nomenclature based on host association has any phylogenetic significance and provide new insights to the concept of host-based nomenclature in Pestalotiopsis species (Jeewon, et al., 2004).

Phylogenies generated here indicated a close relationship among morphologically related species rather than association with host, and hence, results from this study have important implications for fungal biodiversity studies, given that naming of species based on host is not valid, the high number of species reported in literature may an overestimate. Many taxa may be nonspecific. It has been shown in this study that several Pestalotiopsis species or multiple strains of the same species can occur on an individual host and this confirms previous findings by Suto and Kobayashi, (1993), Kim et al.,(1997) and Hopkins and Quilken,(2000).

\section{REFERENCES}

1. Arrhenius SP and JH. Langenheim. 1986. The neotropical distribution of Pestalotia on the leguminous tree genera Hymenaea and Copaifera. Mycologia 78: 673-676.

2. Elliott, M. L. 2006. Pestalotiopsis (Pestalotia) Diseases of Palm. Plant Pathology Department, Florida Cooperative Extension Service, IF AS, University of Florida (PP-217).

3. Fail, GL.and JH. Langenheim. 1990. Infection processes of Pestalotia subcuticularis on leaves of Hymenaea courbaril. Phytopathology 80: 1259-1265.

4. Gepts, P. 1993. The use of molecular and biochemical markers in crop evolution studies. pp. 51-94. In: (M.K. Hecht, ed.) Evolutionary Biology, Vol. 27. Plenum Press, New York.

5. Hewitt, EJ. 1952. Sand and water culture methods used in the study of plant nutrition,-Commonwealth Bureau Bot. Plantation Crops Tech. Commun. 22: 405439.

6. Hopkins, K.E. and M.P. Mc Quilkin. 2000. Characteristics of Pestalotiopsis associated with hardy ornamental plants in the UK. Eur. J. Plant Pathol., 106:7785.

7. Jeewon, R., E.C.Y. liew, and K.D. Hyde. 2004. Phylogenetic evaluation of species nomenoculture of Pestalotiopsis in relation to host association. Fungal Diversity 17: 39-55.

8. Joshi, M.S. 2005. Leaf blight of cashew incited by Pestalotia heterocornis Guba. Ind. Phytopathology, 58 (NO.2). 
9. Lisa M. Keith, Maile E. Velasquez, and T. Zee. Francis. 2006. Identification and Characterization of Pestalotiopsis spp. Causing Scab Disease of Guava, Psidium guajava, in Hawaii. Plant Dis., 90: 16-23.

13. KerChung, Kuo and H.C. Hoch. 1996. The parasitic relationship between Phyllosticta ampelicda and Vitis vinifera. Mycologia, 88: 626-634.

14. Kim, K.S., H.S. Choi, T.H. Lim, T.H. Chang, B.K. Chung, M. J. kim, and Y.S. Lee. 1997. Genetic diversity of leaf blight pathogen of sweet persimmon Pestalotipsis species with random amplified polymorphic DNA (RAPD). Korean J.of mycol., 13: 311-316.

15. Ko, Y., K.S. Yao, C.Y. Chen, and C.H. Lin. 2007. First report of gray leaf spot of mango (Mangifira inddica) caused by Pestalotiopsis mangiferae in Tiwan. Plant Dis. 91 (12):1684B.

16. Ozoe, S., T. Takuda, and R. Kawamoto. 1967. Studies on the ecology and control of the Pestalotia vine rot of grape. Bulletin of the Shimane Agric. Exp. St. 8: 1122.

17. Uchida, J. Y. 2004. Pestalotiopsis diseases. Pages 27-28 in (M. L. Elliott, T. K. Broschat, J. Y. Uchida, and G. W Simone, eds.)Diseases and Disorders of Ornamental Palms. American Phytopathological Society, St. Paul, MN.

18. Raynor, R. W. 1970. A Mycological Colour Chart. Commonwealth Mycol. Inst., Kew, Surrey, England.

19. Suto,Y. and T. Kobayashi. 1993. Taxonomic studies on the species of Pestalotiopsis, parasitic on conifers in Japan. Trans. Mycol. Soc., Japan, 34: 323344.

20. Townsend, G.R. and J.W. Heuberger. 1943. Method for estimating losses caused by diseases in fungicide experiments. Plant Dis. Reptr., 27: 340.

21. Welsh, 3. and M. McClelland. 1990. Fingerprinting genomes using PCR with arbitrary primers. Nucleic Acid Res., 18: 7213-7218.

22. Williams, J. G. K., A. R. Kubelik, K. J. Livak, J. A. Rafaiski and S. V. Tingey. 1990. DNA polymorphisms amplified by arbitrary primers are useful as genetic markers. Nucleic Acids Res., 18: 6531-6535. 


\section{الصفات المورفولوجية و التحليل العنقودى لأنماط ال الدنا \\ لفطربستالوشيوبسيس و علاقتها بالعائل}

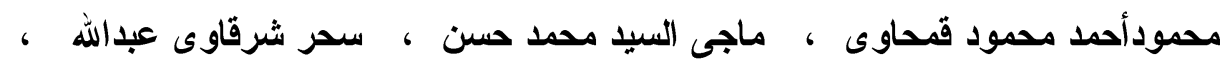
نها فريل بدوى نميل محمد

$$
\text { معهُ بحوث أمراض النباتات- مركز البحوث الزراعية- جبزة- مصر }
$$

أوضحت العدوى المتبادلة لعدد 15 عزلة بستالوشيوبسيس و المتحصل عليها من عو ائل و

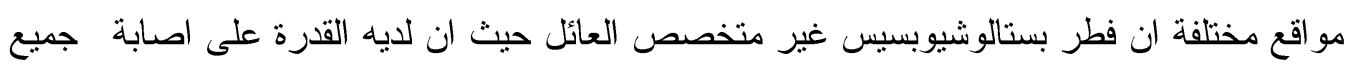

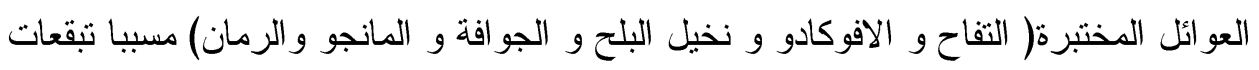

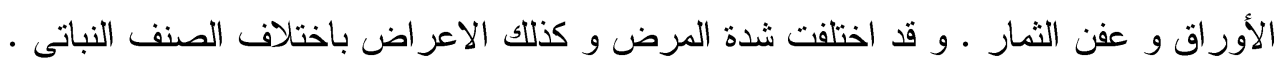

كانت نباتات الجو افة الاكثر قابلية للاصابة بجميع العزلات المختبرة مسببة بقع بنية على الأور اق

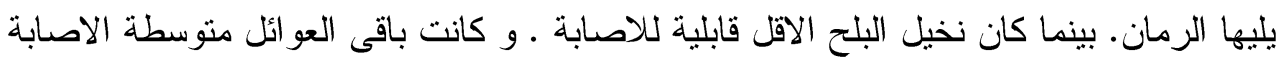

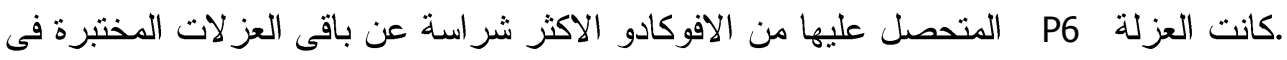

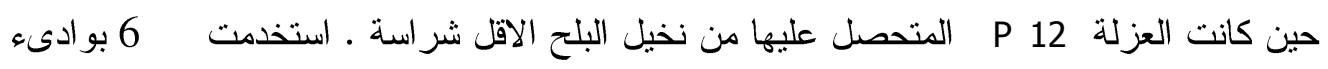

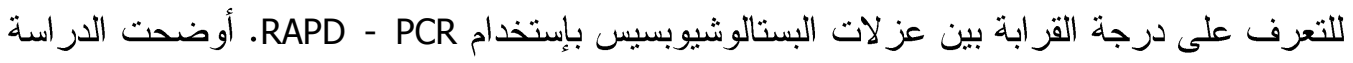

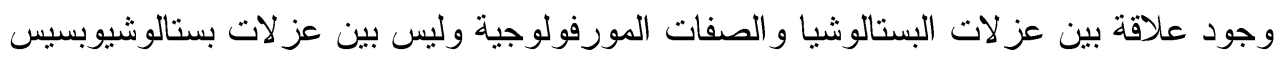
و العائل المعزولة منه. 